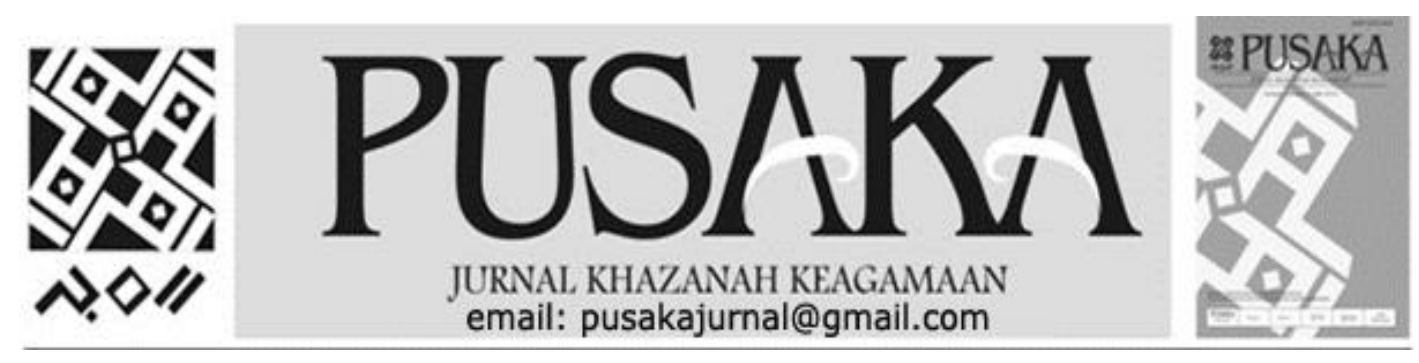

\title{
Pembelajaran Kitab Kuning pada Pondok Pesantren Hidayatullah Ternate
}

\section{Learning of Kitab Kuning In the Islamic Boarding School Hidayatullah \\ Ternate}

Faizal Bachrong

Balai Penelitian dan Pengembangan Agama Makassar

Jl. A.P. Pettarani No.72 Makassar. Telp: 0411-452952

Email: Faizal Bachrong@gmail com.

\begin{tabular}{|c|c|}
\hline $\begin{array}{c}\text { Info } \\
\text { Artikel } \\
\end{array}$ & Abstract \\
\hline $\begin{array}{c}\text { Diterima } \\
20 \\
\text { Februari } \\
2018 \\
\text { Revisi I } \\
25 \\
\text { Maret } \\
2018\end{array}$ & $\begin{array}{l}\text { Pengkajian kitab kuning di Pesantren merupakan unsur penting dari padanya, dan } \\
\text { hal ini secara umum cenderung mengalami kemunduran, karena berbagai hal. } \\
\text { Karena itu pengkajian tentang pemanfaatan kitab kuning di pesantren penting } \\
\text { dilakukan. Penelitian ini menyoroti realitas pengkajian kitab kuning di pesantren. } \\
\text { Fokus penelitian ini adalah PP HIdayatullah Ternate. Karena penelitian ini } \\
\text { merupakan penelitian kualitatif, maka teknik pengumpulan datanya adalah } \\
\text { wawancara, observasi dan studi dokumen dan pustaka. Analisis datanya adalah } \\
\text { deskreprif kualitatif. PP Hidayatullah Ternate termasuk pondok pesantren } \\
\text { kombinasi yang selain membina satuan pendidikan formal berupa sekolah dan } \\
\text { madrasah, juga membina kepesantrenan, termasuk pengajian kitab. Santri yang } \\
\text { dibina di dalamnya laki-laki dan perempuan. Dalam program kepesantrenan } \\
\text { selain salat berjemaah, hafalan Al Alquran dan hadits, juga ada taklim diniyah } \\
\text { (pengkajian kitab) dan ada halaqah diniyah. Pengkajian kitab memilih } 5 \text { kitab } \\
\text { yang digariskan oleh Pengurus Pusat Hidayatullah berkaitan dengan Aqidah, } \\
\text { Fiqih, Tafsir. Sirah dan Bahasa Arab. Para pengajarnya adalah kader-kader } \\
\text { Hidayatullah sendiri dan lainnya. Pengkajian kitab ini dengan metode ceramah } \\
\text { dan kitab pegangannya adalah terjemahannya. Santri hanya mendengar tanpa } \\
\text { memiliki kitabnya. Kendala utama adalah kemampuan berbahasa Arab uantuk } \\
\text { pengkajian kitab, terutama bagi santri yang dapatdigolongkan tidak memilikinya. } \\
\text { Kata Kunci: Pondok Pesantren, Hidayatullah Ternate, Pengkajian kitab. }\end{array}$ \\
\hline $\begin{array}{c}\text { Revisi II } \\
5 \\
\text { April } \\
2018\end{array}$ & $\begin{array}{l}\text { The study of the Kitab Kuning at the Islamic Boarding School is an important } \\
\text { element of it, and this generally tends to decline, because of various things. } \\
\text { Therefore, the study of the use of yellow books in pesantren is important. This } \\
\text { research highlights the reality of the study of the yellow book in pesantren. The } \\
\text { focus of this research is PP Hidayatullah Ternate. Because this research is a } \\
\text { qualitative research, the data collection techniques are interviews, observation and } \\
\text { study of documents and literature. Data analysis used a qualitative descriptive } \\
\text { approach. PP Hidayatullah Ternate includes a combination Islamic boarding } \\
\text { school. In the pesantren program besides praying in congregation, memorizing the } \\
\text { Alquran and hadith, there are also taklimdiniyah (study of the book) and there is } \\
\text { halakah diniyah. The book study chose } 5 \text { books outlined by the Hidayatullah } \\
\text { Central Board relating to Aqidah, Fiqih, Tafsir. Sirah and Arabic. The instructors } \\
\text { are Hidayatullah's own cadres and others. The study of this book with the lecture } \\
\text { method and the handbook is the translation. Santri only hear without having the } \\
\text { book. The main obstacle is the ability to speak Arabic for Bible study, especially } \\
\text { for students who can be classified as not having it. } \\
\text { Keywords: Islamic boarding school, Hidayatullah Ternate, study of kitab kuning. }\end{array}$ \\
\hline
\end{tabular}




\section{PENDAHULUAN}

Pesantren merupakan tempat pendidikan moral agama Islam sebagai pedoman hidup bermasyarakat sehari hariyang merupakan lembaga pendidikan keagamaan tertua di Indonesia. Pesantern sendiri munurut pengertian dasarnya adalah tempat belajar para santri. Sedangkan pondok berarti rumah atau tempat tinggal sederhana yang terbuat dari bambu. Disamping itu kata "pondok" mungkin juga berasal dari bahasa arab "fundung" yang berarti hotel atau asrama. (www.sofiti exaf blog spot.com 20 september 2018). Kajian kitab kuning dijadikan prasayarat pengakuan keulamaan seseorang oleh masyarakat. Tingkat keulamaan seseorang ditentukan oleh kemampuannya dalam menjelaskan setiap kalimat dari kitab yang dikaji (Burhanuddin, 2012: 358-359.) Kemampuan dan penguasaan kitab kuning oleh kiyai suatu pesantren, menentukan kepopuleran pesantren itu. Karena itu, kajian kitab kuning menjadi bagian yang tak terpisahkan dalam sistem kurikulum suatu pesantren.

Pesantren atau Pondok Pesantren adalah sebutan bagi tempat yang mengkaji "kitab-kitab kuning" (kitab kuno). Pesantren identik dengan pesantren tradisional (klasik) yang berbeda dengan pesantren modern dalam hal metode pengajaran dan infrastrukturnya.

Di pesantren, hubungan antara Kiai dengan santri cukup dekat secara emosional. Kiai terjun langsung dalam menangani para santrinya.

Pada dasarnya, pesantren adalah bentuk asli dari lembaga pesantren itu sendiri. Sejak munculnya pesantren, format pendidikan pesantren adalah bersistem salaf. Kata salaf merupakan
Bahasa Arab yang berarti terdahulu, klasik, kuno atau tradisional. Seiring berkembangan zaman, tidak sedikit pesantren salaf yang beradapasi dan meng-kombinasikan sistem pembelajaran modern.

Dalam klasifikasi tipe pesantren di lingkungan Kementerian Agama, disebut sebagai Pesantren Kombinasi. Kementerian Agama membagi tiga tipe pesantren, yaitu pesantren salafiyah, pesantren khalafiyah (Ashriyah) dan pesantren Kombinasi. (www. wikipedia.org/wiki 20 september 2018)

Dalam perjalanan waktu, kurikulum di pesantren tidak hanya mengacu pada kajian kitab kuning. kajian kitab kuning menjadi tereduksi, pesantren mengalami transformasi dalam berbagai bentuk, Bahkan banyak pesantren yang sudah tidak mengajarkan kitab kuning lagi. Pemerintah melalui PMA nomor 13 Tahun 2014 mentolerir hal ini sebagaiaman terlihat pada pasal 5 menyebutkan bahwa Pesantren wajib memiliki pengajian kitab kuning atau Dirasah Islamiyyah dengan pola Mu'allimin. (PMA No. 13 Tahun 2014)

Bertitik tolak pada latar belakang yang telah dikemukakan, dirumuskan masalah penelitian ini, yaitu: Bagaimana pembelajaran kitab kuning pada Pondok Pesantren Pesantren Ternate? Dari masalah ini dirumuskan pertanyaan penelitian yang diangkat sebagai sub masalah penelitian ini, yaitu:

1. Apa jenis kitab kuning yang diajarkan di Pondok Pesantren Hiyatullah Ternate?

2. Bagaimana mekanisme pemanfaatan kitab kuning di Pondok Pesantren Hidayatullah Ternate? 
3. Bagaimana problem dan solusinya pemanfaatan kitab kuning di pondok pesantren?

Penelitian ini merupakan penelitian deskreptif kualitatif. Metode pengumpulan data yang digunakan yaitu wawancara. (Cresswell, 1994) berpasangan dengan teknik observasi/ pengamatan serta dokumentasi. Untuk memperkuat, teknik pengumpulan data tersebut, dilakukan studi kepustakaan atau referensi yang berkaiatan dengan kajian ini.

\section{Tinjauan Kepustakaan}

Nasaruddin Umar membagi
pesantren berdasarkan tipe
pendidikannya ke dalam empat tipe,
yaitu:

1. Pesantren yang menyelenggarakan pendidikan formal dengan menerapkan kurikulum nasional.

2. Pesantren yang menerapkan kurikulum keagamaan dan ilmu umum namun tidak mengikuti kurikulum nasional

3. Pesantren yang hanya mengajarkan ilmu agama.

4. Pesantren yang hanya sekedar menjadi tempat pengajian. (Umar, 2014: 27-28)

Amin Haedar mengemukakan tipologi pesantren yang hampir mirip tersebut sebagaimaan dikuti oleh Mardiyah. Yang membedakan hanya pada tipe ketiga yaitu Pesantren yang mendirikan Madrasah Diniyah. (Mardiyah, 2013 466:)

Pada tahun 1994, Balai Penelitian Lektur Keagamaan Ujung Pandang menerbitkan hasil penelitiannya berjudul transformasi kelekturan pesantren di Sulawesi Selatan. Kajian ini menyorot lima pesantren, yaitu: Pesantren As'adiyah Sengkang, Pesantren Manahil Ulum Kaballangan
Pinrang Pesantren Al Urwatul Wustqa Sidrap Pesantren Babul Khaer Bulukumba dan Pesantren Darul Istiqamah Maros Kelima pesantren tersebut merupakan pesantren yang mengkombinasikan antara kurikulum khas kepesantrenan berupa kitab kuning kurikulum Deprtemen Agama dan Depertemen Pendidikan. Kajian ini menyebutkan beberapa kitab kuning yang dikaji di pesantren. (As'ad, 1994 76-77:)

Perhatian Balai Litbang Agama Makassar terhadap kajian pesantren tinggi terliahat bahwa pada tahun 2011, diadakan penelitian Implementasi Pengajian Kitab Pada Pondok Pesantren di Kawasan Timur Indonesia. Sebagian dari kajian telah diterbitkan dalam buku yang berjudul Reinversi Kurikulum dan Pembelajaran Pendidikan Agama dan Keagamaan. (Mujizatullah, 2011 171-256:)

Defenisi yang lebih luas tentang kitab kuning disebutkan dalam KMA nomor 13 tahun 2014 pasal 1 (3) Kitab Kuning adalah kitab keislaman yang berbahasa Arab yang menjadi rujukan tradisi keilmuan di Pesantren. Pada realitasnya, kitab-kitab seperti itu diajarkan juga pada pengajian halaqah di masjid tertentu.

\section{PEMBAHASAN}

Kota Ternate merupakan wilayah kepulauan yang meliputi 8 buah pulau, 3 di antaranya merupakan pulau kecil yang luasnya sekitar $0,5 \mathrm{~km} 2$ dan tidak berpenghuni, dan hanya 5 pulau yang berpenghuni, yaitu: P.Ternate, P.Hiri, P.Moti, P.Mayau, dan P.Tifuri. Kota Ternate dibagi menjadi 8 kecamatan dan dihuni oleh penduduk (2016) 218.028 jiwa, terdiri atas laki-laki sebanyak 110.725 orang $(50,78 \%)$ dan perempuan sebanyak 107.303 orang 
(49,22\%). (BPS, Ternate 2017 171256:)

Mayoritas penduduk Kota Ternate tersebut menganut agama Islam, yaitu 215.267 orang $(96,49 \%)$. Yang menganut agama Kristen hanya 6.749 orang $(3.02 \%)$, dan selebihnya sebanyak 1.091 orang $(0,49 \%)$ menganut agama-agama Katholik, Hindu Budha dan Kongchucu.

Komposisi Penduduk Kota Ternate Berdasarkan Pemelukan Agama pada Setiap.
Kecamatan. Tahun 2016. (BPS Temate, 2017:
\begin{tabular}{|l|c|c|c|c|c|c|c|}
\hline \multicolumn{1}{|c|}{ Kecamatan } & Islam & Kristen & Katholik & Hindu & Budha & Konhucu & Jumlah \\
\hline 1 & 2 & 3 & 4 & 5 & 6 & 7 & 8 \\
\hline 1.P. Ternate & 15.200 & 172 & 2 & 0 & 0 & 0 & 15.374 \\
2. Moti & 5.097 & 0 & 0 & 0 & 0 & 0 & 5.097 \\
3.P.BatangDua & 6 & 2.890 & 3 & 0 & 0 & 0 & 2.899 \\
4.P. Hiri & 2.908 & 0 & 0 & 0 & 0 & 0 & 2.908 \\
5.Ternate Selatan & 79.815 & 880 & 71 & 16 & 28 & 8 & 80.818 \\
6.Ternate Tengah & 60.669 & 2.336 & 598 & 138 & 28 & 145 & 63.914 \\
7 Ternate Utara & 51.572 & 471 & 39 & 1 & 14 & 0 & 52.09 \\
\hline Kota Ternate & 215.267 & 6.749 & 713 & 155 & 70 & 153 & 223.107 \\
\hline
\end{tabular}

Pada tabel di atas jelas terlihat bahwa kecuali Kecamatan P. Batang Dua mayoritas penduduknya beragama Islam, bahkan pada kecamatan Moti dan Kecamatan P. Hiri semua penduduknya beragama Islam. Sedang pada Kecamatan P. Batang Dua hampir semuanya beragama Kristen. Dari penduduk berjumlah 2.899 orang yang beragama Islam hanya 6 orang dan yang beragama Katholik hanya 3 orang.

Rumah ibadah bagi umat Islam, berupa masjid 197 buah tersebar pada semua kecamatan yang ada kecuali pada Kecamatan Pulau Batang Dua karena rumah ibadah di kecamatan ini hanya bagi umat Kristen (gereja) berjumlah 10 buah dari 18 gereja bagi umat Kristen di Kota Ternate

Jumlah Madrasah di Kota Ternate, Tahun 2017/2018.MI 13 buah, MTs 11 buah, dan MA 6 buah. Madrasah swasta ada yang yang bernaung di bawah pesantren. Pondok pesantren yang tercatat pada Kantor Kemenag Kota Ternate hanya tiga lembaga, yaitu: Pondok Pesantren Alkhairaat, Pondok Pesantren Moluku Kie Raha, dan Pondok Pesantren Hidayatullah Ternate. (Ahmad, . H 5:)

\section{Pondok Pesantren di Kota Ternate}

Pondok pesantren yang tercatat pada Kantor Kemenag Kota Ternate hanya 3 buah, yaitu: 1 . PP Al Khairaat Kalumpangt Ternate, 2. PP Hidayatullah Ternate, dan 3. PP Moluku Kie Raha Ternate. Selain itu, diketemukan dua pesantren lainnya, yaitu: 1. PP Ulumuddin Ternate dan 2. PP Darut Tahsin Ternate.

PP Al Khairaat Kalumpang Ternate yang berdiri sejak tahun 1964 M/1374 $\mathrm{H}$ bernaung di bawah Yayasan Al Khairaat Cabang Kota Ternate. Pondok pesantren ini beralamat di Jl. Kakatua No. 155 Kelurahan Kalumpang, Kecamatan Ternate Tengah. Sebagai lembaga pendidikan, PP Al Khairaat Ternate membina satuan pendidikan berupa sekolah dan madrasah dari tingkat Sekolah dasar sampai tingkat menengah atas. Pendidikan formal yang diasuh oleh pondok pesantren ini adalah: 1. SD 01 Alkhairaat; 2. SD 04 Alkhairaat; 3. SMP BP Alkhairaat; 4. MTs Alkhairaat; 5.SMA Alkhairaat; dan 6. MA Alkhairaat.

PP Alkhairaat pada tahun pelajaran 2017-2018 menampung siswa pada semua jenjang dan jenis satuan pendidikan tersebut sebanyak 1.206 orang, terdiri atas laki-laki sebanyak 683 orang dan perempuan sebanyak 523 orang. Siswa tersebut diasuh oleh tenaga pendidik sebanyak 108 orang, yang rinciannya adalah: guru tetap PNS sebanyak 82 orang, guru tetap Yayasan 3 orang, dan guru tidak tetap sebanyak 23 orang. Hal ini menunjukkan bahwa 
bantuan Pemerintah berupa tenaga pendidik sangat besar.

Sebagai pondok pesantren, tentu ada santri yang mondok di dalamnya. Kenyataannya, saat ini santri yang mondok sangat sedikit jumlahnya dibanding jumlah siswa yang seharusnya mondok, hanya 20 putra. Santri yang mondok ini mempergunakan waktu sesudah salat magrib untuk pembelajaran, hanya saja hampir tidah ada pengajian kitab kecuali Hadits, yaitu Hadits Arbaiin.

PP Hidayatullah Ternate adalah salah satu dari sekian banyaknya pondok pesantren Hidayatullah yang tersebar di berbagai daerah di Indonesia. Pondok pesantren Hidayatullah yang berpusat di Balikpapan, Kalimantan Timur tersebar secara meluas di banyak tempat di Nusantara ini terutama di Kawasan Timur Indonesia Mengiringi pondok pesantren Hidayatullah didirikan ormas Islam Hidayatullah yang berscop nasional dan berpusat di Jakarta. Ormas ini yang misi utmanya di bidang pendidikan dan dakwah sangat komitmen dalam membangun lembaga pendidikan Islam terutama pondok pesantren sehingga pondok-pondok pesantren binaan Hidayatullah tersebar di berbagai polosok Nusantara Indonesia.

Hidayatullah sebagai organisasi sosial keagamaan, struktur organisasinya tertata dengan baik dari pusat ke daerah. Untuk tingkat pusat, terdapat Dewan Pimpinan Pusat yang berpusat di Jakarta, untuk tingkat propinsi ada Dewan Pimpinan Wilayah (DPW), dan untuk tingkat kabupaten kota ada Dewan Pimpinan Daerah (DPD).

Kepemimpinan Hidayatullah dibangun di atas manhaj nubuwwah yang melangkah mengikuti skala priorotas, mulai dari yang paling asasi (ushul) hingga yang merupakan cabang (furu') Sedangkan agenda utama yang menjadi fokus program pesantren Hidayatullah adalah imamah dan jamaah (tajdid); pencerahan kesadaran; pembersihan jiwa (tazkiyah an nufus); pengajaran dan pendidikan:(taklim wal hikmah); menuju kepemimpinan dan umat yang moderat (washatan) dan terbaik. (Ahmad. H 5:)

Pondok Pesantren Moluku Kie Raha beralamat di Koloncucu Puncak, Kelurahan Toboleu, Kecamatan Ternate Utara. Pondok Pesantren yang berdiri sejak tahun 2010 bernaung di bawah Yayasan Al Mulk Kie Raha. Satuan pendidikan yang dibina di dalam pondok pesantren ini madrasah tsanawiyah, yaitu MTs Ulumul Alquran. Siswa yang dibina pada madrasah tsanawiyah ini sebanyak 24 orang, laki-laki 21 orang dan perempuan 3 orang. Siswa tersebut terkelompok pada tiga kelas, yaitu: kls VII 8 orang, kls VIII 10 orang, dan kelas IX 6 orang. Madrasah ini dibina oleh tenaga pendidik sebanyak 19 orang. Sebagian pondok pesantren, sebagian besar siswa Madrasah Tsanawiyah tergolong santri mondok, yaitu sebanyak 13 orang dari siswa sebanyak 24 orang. Santri yang mondok sebanyak 18 orang termasuk 13 orang tersebut ditambah 2 orang dari Madrasah Ibtidaiyah dan 3 orang siswa SMA yang belajar di luar kampus. Pembacaan kitab di pesantren ini dilakukan secara terbatas.

Di samping Madarasah Tsanawiyah, pesantren ini juga membina satuan pendidikan tingkat dasar, yaitu Madrasah Ibtidaiyah Ulumul Alquran Wahdah Islamiyah. Dicantumkannya nama Wahdah 
Islamiyah pada madrasah ini memberi petunjuk bahwa pesantren ini dibina oleh organisasi Wahdah Islamiyah yang berpusat di Makassar. Madrasah ini masih berumur mudah, baru berjalan 3 tahun. Pada tahun pelajaran 2017-2018, membina murid sebanyak 27 orang yang terkelompok pada 3 kelas, yaitu kelas I 6 orang, kelas II 9 orang, dan kelas III 12 orang. Madrasah ini dibina oleh tenaga pendidik sebanyak 9 orang, termasuk kepala madrasah.

PP Ulumuddin merupakan pesantren tahfizul Alquran yang bernaung di bawah Yayasan Ulumuddin Maluku Utara dan beralamat di Komplek Perumahan Fola Raha Bukit Kelurahan Kalumata Kecamatan Ternate Selatan. PP Ulumuddin yang saat ini dipimpin oleh seorang kiai yang masih muda (34 tahun) berdiri sejak tahun 2009 dan membina santri (2018) sebanyak 38 yang bervariasi umurnya antara 13 th 17 th. Santri pada pondok pesantren ini betul betul fokus pada pengajian pesantren, tidak ikut dalam pendidikan formal di luar pesantren. Selain tahfiz, santri juga mengikuti pengajian kitab dari kiainya berkaitan dengan cabangcaabang ilmu Fikih, Hadits, dan Sirah. Kitab Fikhi yang diajarkan dari Imam Mazhab Empat. Sedang kitab hadits adalah Bukhari Muslim. Adapun kitab sirah yang diajarkan adalah Syairrahman. Untuk mendapatkan syahadat, evaluasi kemampuan sangat ketat, sehingga baru satu orang yang dinyatakan berhasil, yaitu Hafiz Abd. Salam.

Kampus yang di tempati saat ini pada alamat tersbut hanya berupa rumah berlantai dua yang tidak terlalu besar. Lantai duanya berfungsi sebagai Musalla, tempat belajar, dan tempat tidur santri. Untuk pengembangannya, pesantren ini sudah memiliki malahan sekitar 2 hektar beralamat di Pitu Kecamatan Ternate Selatan.

PP Darut Tahsin yang bernaung di bawah Yayasan Darut Tahsin Ternate adalah pondok pesantren di Kota ternate yang sangat muda usianya, dimulai pada awal-awal 2018. Yayasan ini cendeng sebagai yayasan keluarga, tidak bernaung di bawah suatu organisasi. Donatur utama yayasan ini adalah H. Muhammad Dg. Barang dan H. Ibrahim. Keduanya termasuk pengusaha sukses di Ternate. Kepemimpin yayasan ini dipercayakan kepada Hj. Sahibah Dg. Barang, saudara H. Muhammad Dg Barang.

Melihat namanya dapat dipahami bahwa pesantren ini fokus pada bacaan Alquran yang benar disamping tahfiz Alquran. Santri diajar membaca Al Alquran dengan lancar, benar dan baik. Mengkaji Al Alquran dari segi qiraahnya, dan juga menghafal Al Alquran. Direncanakan lama belajar santri 3 tahun, setiap semester santri dibebankan menghafal 5 juz, sehingga selesai 3 tahun sudah hafal 30 juz.

Ada tiga kegiatan pembelajaran Al Alquran yang diprogramkan dalam pondok pesantren ini, yaitu TPQ/TKQ, pesantren $\mathrm{Al}$ Alquran, dan MTB (Metode Tartil Bersajak). Santri yang ikut pada pesantren semuanya modok dan berada pada usia SD dan SMP. Jumlah santri mondok ini sebanyak 42 orang, laki-laki 21 orang dan perempuan 21 orang. Adapun yang ikut pada program Tahsin dengan MTB semacam santri kalong yang tergong anak muda. Mereka biasanya belajar pada malam hari. Sementara ini ada 3 kelompok santri kalong ini, yaitu: 1 . mahasiswa IAIN Ternate 6 orang, 2 . Santri Tahfiz Gambessi Pondok 
pesantren ini bernaung di bawah Yayasan Darut Tahsin Ternate. Yayasan ini cendeng sebagai yayasan keluarga7 orang, 3. Berbagai latar belakang 8 orang.

Kiainya seorang ahli qiraah dan hafiz berasal dari Lombok Nusa Tenggara Barat, bernama Ihsanuddin Al-Lambaqiy, S.Pd.I (35 th) alumni dari PTIQ Jakarta tahun 2009. Sebelum belajar di PTIQ telah menimba ilmu di Pondok Pesantren Uswatun Hasanah di Lombok sampai 2001. Selanjutnya belajar kitab kuning pada pondok pesantren Hidayatuttullab di Kediri sampai 2004. Kepakarannya dari segi qiraah mendapat pengakuan dengan bersanad ke 37.

Kiai pesantren, Ihsanuddin AlLambaqiy, S.Pd.I sengaja didatangkan oleh pengurus yayasan untuk memimpin pesantren tersebut. Pesantren ini baru dibuka pada Januari 2018. Santri yang diterima laki-laki dan permpuan dan dipondokkan pada pondok yang berbeda dalam kampusnya yang merupakan bahagian dari pemilik yayasan. Pesantren ini dibina 4 orang, yaitu kiainya sendiri dibantu oleh 3 orang, termasuk isterinya dan 2 orang lainya, laki-laki 1 orang dan perempuan 1 orang.

\section{Profil PP Hidayatullah Ternate}

PP Hidayatullah Ternate bernaung di bawah Yayasan Pondok Pesantren Hidayatullah Ternate. Yayasan ini berada dalam binaan Dewan Pengurus Daerah (DPD) Hidayatullah Kota Ternate. PP Hidayatullah Ternate membina santri putra dan santri putri yang keduanya berada pada kampus yang berbeda dengan jarak sekitar $1 \mathrm{~km}$. Kampus putra berada di Jl. Tengah Kalimata dan kampus putri terletak di Kalimata
Puncak. Kedua kampus ini dalam wilayah Kecamatan Ternate Selatan.

Areal kampus I, putra berada di tengah-tengah pemukiman penduduk. Aral ini relatif sempit dengan topografi berbukit. Peletakan bangunan disesuaikan dengan topografi tersebut sehingga kelihatan bertingkat-tingkat. Areal paling atas sebelah timur terletak gedung SMP yang bertingkat dua, terdiri dari 8 lokal. Di sebelah selatannya terdapat gedung-gedung: masjid lama (masjid At Taqwa), masjid baru (masjid Al Hasan), gedung yang ditempati RA, gedung yang ditempati kantor yayasan. Semua gedung-gedung ini konstruksi permanen bertingkat dua. Bagian selatan areal berderetan dengan gedung kantor terdapat bangunan baru yang direncanakan bertingkat dan baru selesai tingkat dasar yang difungsikan sebagai asrama. Gedung lama, masjid At Taqwa tidak difungsikan kecuali sebagian lantai dasarnya sebagi rumah Pembina. Kampus ini dibelah oleh jalan kampus bermula dari pintu gerbang di jalan tengah Kalumata sebelah selatannya mendaki sampai depan gedung SMP dan membelok ke timur masuk pemukiman penduduk. Di sebelah barat jalan kampus terletak lapangan upacara atau olah raga. Jalan kampus ini selalu terbuka untuk dilewati penduduk di sebelah timur kampus karena sebelumnya merupakan jalanan penduduk.

Areal kampus II, Putri berada pada lereng Gunung Gamalama sehingga disebut Kalumata Puncak. Luas areal ini sekitar $4050 \mathrm{~m} 2$, memanjang dari timur ke barat dan di depannya terdapat jalan raya. Di seberang jalan depan kampus terdapat 5 unit rumah untuk pengasuh pesantren. Semua gedung berlantai satu kecuali satu gedung yang panjangnya hanya 
dua lokal berlantai dua. Gedung ini berfungsi sebagai asrama bersama gedung lainnya yang sejejer dengannya. Gedung-gedung pada bagian timur kampus berfungsi sebagai ruang belajar dan kantor madrasah/sekolah. Bagian tengah sebagai asrama dan bagian barat sebagai rumah pengasuh. Musalla terdapat pada bagian barat kampus dekat rumah pengasuh.

PP Hidayatullah Ternate sebagai lembaga pendidikan / pondok pesantren didirikan pada tahun 1994. Secara historis, cikal bakal pondok pesantren ini adalah Panti Asuhan AtTaqwa dan selanjutnya berubah nama menjadi Panti Asuhan Al Huda. Anakanak panti asuhan inilah yang menjadi santri PP Hidayatullah Ternate. Para santri dididik secara kepesantrenan dalam kampus dan belajar pada sekolah formal di luar kampus. Pada tahun 2001 PP Hidayatullah membuka sekolah dengan sistim Islamic Boarding School (sekolah Islam berasrama) pada jenjang pendidikan tingkat sekolah menengah pertama (SMP) yang diberi nama SMP Integral Ulul Albab.

Pada 1994/1995 sebagai perintis adalah Ustadz Syafruddin sekaligus pimpinan pertama, dilanjutkan oleh Ustadz Mardhatillah sebagai pimpinan kedua, 1995/1996, pimpinan ketiga Ustadz Abd. Qadir Abdullah, 1996 2000, pimpinan keempat, 2000 - 2005, Ustadz Riadi Poniman. (Ismail, 2007 23-24:) Selanjutnya secara estafet yayasan Hidayatullah di nakhodai masing-masing oleh: Ustadz Ramadhani AK (2005 - 2007); Ustadz Muhammad Kamal (2007 - 20011); Ustadz Ahmad Yasman (2011 - 2016) dan Ustadz Ashar Abdul Gani (2016 - sekarang) (Hasil wawancara saat penelitian).

PP Hidayatullah Ternate membina satuan pendidikan berupa sekolah dan madrasah. Madrasah yang dibina oleh pondok pesantren ini adalah tingkat ibtidaiyah dan aliyah, sedang sekolah yang dibina adalah pada tingkat menengah pertama. Selain itu, juga mengelola pendidikan Anak Usia Dini (PAUD). Satuan pendidikan yang dikelola pada kampus putra adalah SMP BP dan TK Terpadu Ulul Albab. Sedang di kampus putri, satuan pendidikan yang dibina adalah Madrasah Ibtidaiyah dan Madrasah Aliyah. Selain itu, PP Hidayatullah juga membina Pusat Kegiatan Belajar Masyarakat (PKBM), yaitu program pendidikan yang berbasis ekonomi.

Siswa yang dibina oleh PP Hidayatullah dalam keempat satuan pendidikan tersebut sebanyak orang, yang rinciannya terlihat pada tebel berikut.

\begin{tabular}{|l|c|c|c|}
\hline \multicolumn{1}{|c|}{ Sek/Mad } & Rombel & Siswa & Guru \\
\hline \multicolumn{1}{|c|}{1} & 2 & 3 & 4 \\
\hline 1. RA & 2 & 34 & 5 \\
2. MI & 6 & 167 & 15 \\
3. SMP & 6 & 122 & 20 \\
4. MA & 3 & 56 & 13 \\
\hline Jumlah & 11 & 379 & 53 \\
\hline
\end{tabular}

\section{Pembelajaran Kitab Kuning pada PP Hidayatullah Ternate}

Pada pembicaraan tentang profil PP Hidayatullah Ternate yang telah dikemukakan, terlihat santri putra dan santri putri masing-masing ditempatkan pada kampus yang berbeda. Oleh karena kedua kampus ini berada dalam suatu managemen, pengelolaannya dalam 1 x 24 jam pada dasarnya sama. Kehidupan santri dalam kampus diatur 
oleh tata tertib yang memuat kegiatan harian yang dilakoni para santri secara rutin. Pada kampus putra, jadwal kegiatn harian sebagai berikut:

Jadwal Kegiatan Harian Santri Putra Tahun Ajaran 2017 - 2018

04.00-05.00 : Salat Lael;

05.00-06.00 : Salat subuh + Wirid;

06.00-07.00 : Mandi, Makan,

Uniforming;

07.00-08.30 : Hafal al Alquran;

08.30-12.30 : Pelajaran Kelas;

12.30-14.00 : Salat Zuhur + hafal

Hadits, Makan Siang;

14.00-16.00 : Pelajaran Kelas;

16.00-17.00 : Salat Asar + Wirid;

17.00-18.00 : Kebersihan, Olah raga, Istirahat;

18.00-18,30 : Persiapan Salat Magrib;

18.30-20.30 : Salat Magrib,

Diniyah, Salat Isya+ Wirid;

20.30-21.30 : Makan Malam;

21.30-22.00 : Belajar Mandiri, Kerja

PR;

22.00-04.00 : Istirahat Malam.

Dalam jadwal kegiatan tersebut, terlihat pendidikan formal dilakukan dua kali sehari, yaitu 08.30 - 12,30 dan $14,00-16,00$. Sebelum siswa masuk belajar di kelas dilakukan aktivitas hafalan Alquran dari 07,00 - 08,30.

Kegiatan kepesantrenan dilakukan berupa pembiasaan atau latihan dan pengajaran. Pembiasaan dan latihan untuk mengerjakan salat, baik sunat maupun wajib. Salat sunat yang dibiasakan adalah salat Tahajud (salat Lael) dan salat Dhuha. Salat Fardhu dilakukan secara berjamaah setiap waktu salat. Salat-salat sunah Rawatib sering dianjurkan tetapi kurang penekanan, terutama salat sunat tahiyyat masjid hampir tidak ada santri yang melakukannya. Pembacaan wirid berpedoman pada susunan wirid yang disusun untuk kalangan Hidayatullah dilakukan 3 kali sehabis salat fardhu, yaitu sesudah salat subuh, sesudah salat Asar dan sesudah salat Isya.

Pengajaran kepesantrenan (kegiatan Diniyah) dilakukan berupa 2 kegiatan, yaitu pertama: halaqah diniyah, berupa kajian Al Alquran dan Fiqih (sesudah salat Subuh) dan hafalan Hadits (sesudah salat Zuhur) dan kedua Taklim Diniyah atau pengkajian kitab sesudah salat Magrib. Pengkajian kitab ini pada dasarnya bukan hanya diperuntukkan bagi santri yang mondok tetapi semua jamaah yang ikut salat berjamaah. Taklim ini dilakukan lima kali seminggu, yaitu setiap malam kecuali malam Jumat. Jadwal Taklim diniyah ini terlihat berikut:

\begin{tabular}{|l|l|l|l|}
\hline \multicolumn{1}{|c|}{ Waktu } & \multicolumn{1}{|c|}{ Pelajaran } & \multicolumn{1}{|c|}{ Nama Kitab } & \multicolumn{1}{|c|}{ Ustaz / Muallim } \\
\hline \multicolumn{1}{|c|}{2} & \multicolumn{1}{|c|}{3} & \multicolumn{1}{c|}{4} \\
\hline Malam Senin & Fiqih & Taudhihul Ahkam & Ridwan A. Sune, S,Pdi \\
Malam Selasa & Enseklipedi & Minhajul Muslim & Ahmad Chairullah \\
Malam Rabu & Tafsir & Tafsir As Sa'diy & Hijir \\
Malam Kamis & Bhs. Arab & Alarabiyah baina yadaek & Ashar Abdul Gani, S.Pdi \\
Malam sabtu & Sirah & Al Rahikul Makhtum & Imam Asyhari \\
\hline
\end{tabular}

Dalam jadwal tersebut terlihat nama-nama kelima kitab yang diajarkan berkaitan dengan mata pelajaran tertentu. Penentuan kitab ini ditetapkan oleh pihak pimpinan pusat Hidayatullah sehingga dapat dikatakan kelimanya merupakan pegangan Hidayatullah. Kelima kitab itu berkaitan dengan Fikih, Aqidah, Tafsir, Sirah, dan Bahasa Arab.

Kitab Taudhihul Ahkam yang dijadikan pegangan Ustadz/Muallim hanya terjemahannya yang sudah terekam dalam lattop (tidak ada buku aslinya). Kitab Minhajul Muslim yang memuat Ensiklopode yang dimulai dengan Aqidah, yang dipegang Muallim adalah terjemahannya dan naskah aslnya sebagai referensi, Demikian pula Tafsir As Sa'di ada terjemahannya dan ada naskah asli 
tetapi hanya referensi. Judul asli dari kitab As Sa'di adalah Taesir al Kariem ar Rahman fie Tafsier al Kalam al Mannan. Pengarangnya adalah Syeikh Abdurrahman bin Nashir as Sa'di. Kitab al Rahikul Makhtum yang menjadi pegangan Muallim hanya terjemahannya. Pengarang dari kitab ini adalah Syaekh Shafiyyurrahman al Mubarakfuri. Adapun kitab $A l$ Arabiyah Baena Yadaeka, meskipun berbahasa Arab, tetapi tidak mendukung kemampuan berbahasa Arab untuk pembacaan kitab kuning, tetapi lebih tepat untuk percakapan bahasa Arab. Tepatnya latihan percakapan bahasa Arab.

Kelima ustadz/muallim yang mempertanggung jawabkan pengkajian kelima kitab yang telah dikemukakan, ada merupakan kader binaan Hidayatullah dan ada yang berasal dari luar Hidayatullah dan mengambil bahagian dalam Hidayatullah di Ternate.

Ustadz Ashar Abdul Gani yang saat ini memegang jabatan sebagai Pimpinan PP Hidayatullah Ternate, Pimpinan Yayasan Hidayatullah Ternate, dan Ketua DPD Hidayatullah Ternate, merupakan kader binaan Hidyatullah. Ia adalah putra kelahiran Bone yang pernah menjadi santri pada Pondok Pesantren Biru di Bone pada tingkat Tsanawiyah (1995-1998). Sebagai kader Hidayatullah dimulai saat mondok di PP Hidayatullah Bontang (1999 - 2002) dan mengikuti pendidikan formal pada SMA Hidayatullah. Selanjutnya melanjtkan kuliah pada Sekolah Tinggi Agama Islam Lukmanul Hakim (STAIL) dalam lingkungan Hidayatullah Surabaya dan menyelesaikan S1 (S.Pd,I) pada tahun 2006. Pada tahun ini juga ditugaskan mengabdi pada PP
Hidayatullah Ternate. Pengabdiannya pada Hidayatullah Ternate cukup lama pada Madrasah Ibtidaiyah (MI) sebagai kepala madrasah tahun 2006 - 2016.

Ustadz Ridwan adalah kader Hidayatullah dari Gorontalo yang pernah momdok di Hidayatullah Bitung, kemudian Hidayatullah Gorontalo dan terakhir kuliah pada STAIL Hidayatullah Surabaya seperti Ustadz Anshar dan lulus pada tahun 2007. Kedatangannya di Ternate 2016 atas permintaan Ustadz Ansar.

Ustadz Khairullah adalah kader Hidayatullah dari Ternate yang mondok di Hidayatullah Ternate saat belajar di tingkat SMP. Kemudian lanjut pada PP Hidayatullah Pusat di Balikpapan sampai lulus pada sekolah Menegah atas dan melanjutkan kuliahnya pada Al Biir Makassar dan tamat pada program Diploma. Untuk memperbaiki qiraahnya, ia mengikuti pengajian sebagai santri kalong pada PP Darut Tahsin Ternate.

Dua muallim lainnya yang bukan kader langsung dari Hidayatullah adalah Ustadz Hijir dan Imam Asyhari. Ustadz Hijir adalah putra Ternate yang setamat SMP di Ternate lanjut pada PP Al Irsyad Bondowoso, yaitu pada MAK. Pesantren ini tergolong pesantren modern. Kemudian lanjut pada LIPIA Jakarta selama 3 tahun. Penyelesaian tingkat sarjana pada STAIN Ternate. Adapun Ustadz Imam Asyhari berlatar pendidikan pesantren yang mengajarkan kitab kuning. Pertnah mengikuti pendidikan pesantren pada tiga pesantren, antara lain PP Darussalam Tulung Agung Banyuwangi dan PP Baitul Makrifah, pondok pesantren salafiyah binaan NU. Karena merasa cukup pengajian kitab kuningnya dan faktor lainnya, seperti masalah ekonomi, masalah usia 25 
tahun, maka hanya satu tahun pada tingkat Ulya. Ia merantau ke Ternate pada tahun 2004 dengan bekerja pada sektor nonformal.

\section{Mekanisme Pemanfaatan Kitab Kuning pada PP Hidayatullah Ternate.}

Pengajian kitab dilakukan antara salat Magrib dan salat Isya, yaitu setelah selesai melakukan salat Magrib. Pengajin ini berbentuk halaqah di depan mihrab masjid, Ustadz duduk bersila di tengah menghadap kepada santri ke timur, didepannya pada santri juga duduk bersila membentuk setengah lingkaran bersaf-saf. Di depan Ustadz diletakkan kitab bahasan dan santri tidak ada yang memilikinya dan juga tidak menyediakan buku catatan. Ustadz membahas kitab rujukan dengan pengantar bahasa Indonesia. Metode yang dipergunakan adalah sima'i (cermah). Keterlibatan santri dalam pemnahasan kitab rujukan tidak ada kecuali menyimak paparan ustadz. Ustadz tidak membaca bahasa asli (bahasa Arab) materi bahasan dan menerjemahkannya apalagi menyuruh santri membacanya karena memang santri tidak memilikinya.

\section{Problem dan Solusi Pemanfaatan Kitab Kuning pada PP Hidayatullah Ternate.}

Kitab kuning adalah kata lain dari kitab rujukan umat Islam berbahasa Arab. Karena kitab demikian ini tidak memakai tanda baca, maka biasa juga dinamai kitab gundul. Meskipun sudah banyak kitab kuning yang sudah diterjemahkan ke dalam bahasa Indonesia sehingga membantu mengkaji isinya, tetapi diakui bahwa mengkaji kitab kuning melalui terjemahannya tidak sebaik mengkaji langsung sumber aslinya, karena terjemahan hanya satu versi dari kandungannya.

Mengkaji dan memahami isi kitab kuning tidak dapat dilakukan, tanpa kemampuan yang mamadai dalam penguasaan bahasa Arab, bahkan tidak semua orang yang mampu berbicara dengan bahasa Arab, otomatis mampu mengkaji kitab kuning. Diakui kemampuan berbahasa Arab untuk mengkaji kitab kuning bagi muallim yang mengkaji kitab di lingkungan PP Hidayatullah pada umumnya masih terbatas. Lebih-lebih santri yang mengikuti pengkajian ini.

Selain itu pengadaan kitab tersebut merupakan kesulitan tersendiri sehinga kitab yang dikaji hanya dimiliki oleh muallim. Para santri tidak memilikinya. Bahkan buku aslinya tidak dimiliki semua muallim.

\section{PENUTUP}

Taklim diniyah (pembelajaran kitab kuning) pada pesantren Hidayatullah Ternate diaktifkan kembali pada tahun ajaran 2017/2018 bagi santri di kampus putra. Sedang di kampus putri belum cukup sebulan ini. Pengajian kitab di kampus putri hanya untuk santri dari MA. Kitab yang dijadikan rujukan berkaitan dengan cabang ilmu agama ditentukan oleh Pengurus Pusat Hidayatullah.

Taklim diniyah yang dilakukan pada kedua kampus PP Hidayatullah Ternate sama, baik kitab maupun nama pengajarnya (muallim) hanya waktunya berbeda. Taklim ini dilakukan lima malam dalam seminggu, antara salat Magrib dan salat Isya. Lima orang muallim pengkajian kitab ini adalah para kader Hidayatullah sendiri ditambah ustadz yang direkrut di Ternate. Pegangan muallim dalam 
pengkajiannya adalah terjemahan kitab kuning yang diajarkan dan ada dua muallim yang mengikutkan kitab aslinya sebagai rujukan. Teknik pengkajiannya adalah sistim cermah, muallim menjelaskan santri mendengarkannya tanpa kitab pegangan masing-masing. Santri putra tidak membawa buku catatan dan santri putri membawa buku catatan, bahkan terjadi dialog, sehingga pengkajian lebih hidup.

Problem utama pemanfaatan teks asli kitab yang dikaji adalah kemampuan berbahasa yang dibutukan untuk pengkajian itu sangat minim bagi muallim dan bagi santri sendiri dapat dikatakan hamper tidak ada. Problem kedua adalah pengadaan kitab asli masih menjadi kesulitan.

\section{DAFTAR PUSTAKA}

Ahmad, Abd. Kadir: Pesantren Hidayatullah Gunung Tembak dan Issu Terorisme. Dalam AlQalam Jurnal Penelitian Agama dan Sosial Budaya. No.XIX Tahun XIII, Edisi Januaqri - Juni 2007. Makassar: Balai Penelitian dan Pengembangan Agama Makassar. 2007.

As'ad, Muhammad. Transformasi Kelekturan Pada Pesantren Manahil Ulum Kaballangan dalam "Transformasi Kelekturan Pesantren di Sulawesi Selatan. Ujung Pandang: Balai Penelitian Lektur Keagamaan Ujung Pandang, 1994.

BPS Kota Ternate. Kota Ternate Dalam Angka 2017

Baso, Ahmad. Pesantren Studies $2 a$. Jakarta: Pustaka Afid, 2012.
Burhanuddin, Jajat. Ulama dan Kekuasaan: Pergumulan Elite Muslim Dalam Sejarah Indonesia Jakarta: Mizan, 2012

Cresswell Jhon W.. Research Design,Qualitative and Quantitative Approaches. (California: Thousand Oaks, 1994).

Ismail, Arifuddin. Peswantren dan Radikalisme (Studi Kasus Pesantren Hidayatullah Ternate). Dalam Al-Qalam Jurnal Penelitian Agama dan Sosial Budaya. No.XIX Tahun XIII, Edisi Januari - Juni 2007. Makassar: Balai Penelitian dan Pengembangan Agama Makassar. 2007.

Mardiyah. Kepemimpinan Kiai Dalam memelihara Budaya Organisasi. Cet. II; Yogyakarta: Aditya Media Publishing, 2013.

Mujizatullah. Implementasi Pengajian Kitab Pada Pondok Pesantren Mambaush Shalichin AlHaramain dalam "Reinversi Kurikulum dan Pembelajaran Pendidikan Agama dan Pendidikan Keagamaan. Jakarta: Orbit, 2011.

Peraturan Menteri Agama Nomor 13 Tahun 2014 Tentang Pendidikan Keagamaan Islam.

Umar, Nasaruddin. Rethinking Pesantren. Jakarta: Elex Media Komputindo, 2014. 